
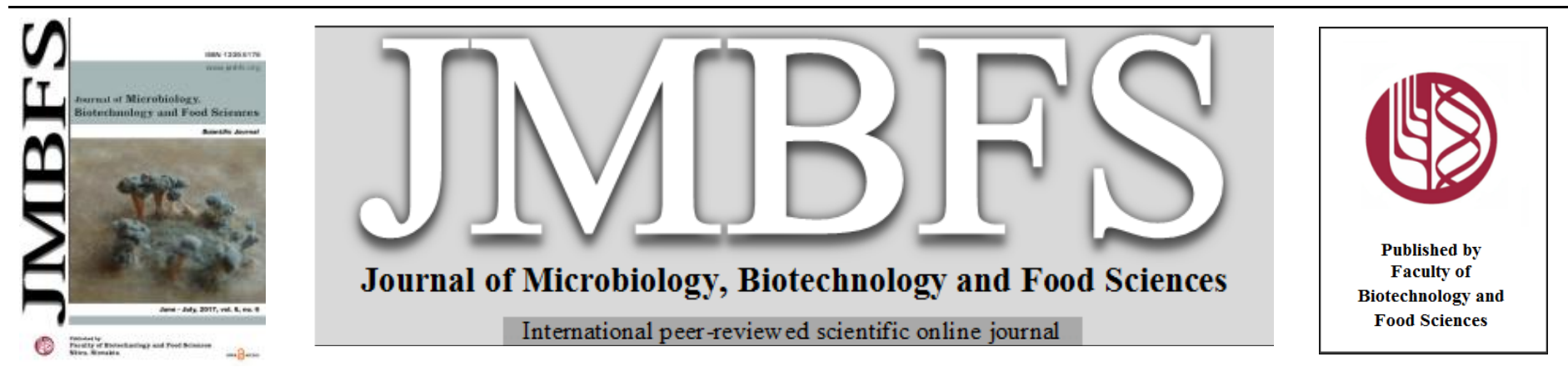

\title{
OPTIMIZATION OF ALPHA AMYLASE FOR BETTER DOUGH PREPARATION
}

\author{
Flory Shobana Maria ${ }^{1}$, Ranjithkumar Rajamani ${ }^{2}$ and Dinesh Bheeman ${ }^{* \# 1}$ \\ Address(es): \\ ${ }^{1}$ Department of Biotechnology, Sree Narayanaguru College, Coimbatore, Tamil Nadu, India. \\ ${ }^{2}$ Department of Biotechnology, Dr.N.G.P. Arts and Science College, Coimbatore, Tamil Nadu, India. \\ *Corresponding author: dinpree@ mail.com
}

doi: $\underline{10.15414 / j \mathrm{mbfs} .2017 .6 .6 .1272-1275}$

\section{ARTICLE INFO}

Received 27. 2. 2014

Revised 17. 1. 2017

Accepted 30. 3. 2017

Published 1. 6. 2017

Regular article

open 2 access

\section{ABSTRACT}

Amylases have potential application in a wide number of industrial processes such as food, fermentation and pharmaceutical industries. The present study mainly focused on screening of amylase producing Bacillus subtilis, production by solid-state fermentation using rice straw and banana pseudo stem and its optimization for amylase activity in dough preparation, effect on bread making and analysis of bread quality. Maximum production of amylase was obtained after $24 \mathrm{hrs}$ of incubation. The optimum $\mathrm{pH}$ for enzyme activity was found to be at $\mathrm{pH} 7$ and the optimum temperature for the activity was found to be at the range of $30-70^{\circ} \mathrm{C}$. The combination of $0.8 \mathrm{~g}$ yeast and $300 \mathrm{U}$ of amylase gave better results than enzyme alone for the better dough preparation.

Keywords: Amylase, Bacillus subtilis, solid state fermentation, optimization

\section{INTRODUCTION}

The industrial enzyme producers sell enzymes for a wide variety of applications and approximately more than $25 \%$ amylases represent as a class of industrial enzymes of the market (Sidhu et al., 1997; Rao et al., 1998). Starch digesting amylase has found important application in bioconversion of starches and starchbased substrates (Fogarty et al., 1983). Amylolytic enzymes are of great significance in biotechnological applications in food industry, amylases can be synthesized from numerous sources, like plants, animals and microorganisms. The enzymes from microbial sources commonly meet industrial demands and had made important contribution to the production of foods and beverages since, microbial amylases have almost completely replaced chemical hydrolysis of starch in starch processing industry (Pandey et al.,2000a; Gupta et al., 2003; Kandra, 2003; Rajagopalan and Krishnan, 2008). Two major classes of amylases have been identified in microorganisms, namely, $\alpha$-amylase and glucoamylase. $\alpha$-Amylases (endo-1,4-a-D-glucan glucohydrolase) are extracellular enzymes that randomly cleave the 1,4-a-D-glucosidic linkages between adjacent glucose units in the linear amylase chain. Glucoamylase (exo1,4-a-D-glucanm glucanohydrolase) hydrolyzes single glucose units from the nonreducing ends of amylose and amylopectin in a stepwise manner (Rameshkumar and Sivasudha, 2011; Nigam and Singh, 1995). Alphaamylase can produce by a wide spectrum of organisms, even though every source produces depend upon biochemical phenotypes that considerably differ in parameters such as $\mathrm{pH}$ and temperature optima as well as metal ion requirements. Submerged fermentation (Smf) has been a traditional way for production of industrially significant enzymes since long past due to multiple facilities like better control over environmental factors namely, $\mathrm{pH}$, temperature, aeration, and moisture level. Cultures reported to be utilized for amylase production using SmF belong to a variety of Bacillus species like Bacillus sp.PN5, Bacillus subtilis JS2004, Bacillus sp. IMD 435, Bacillus sp. I-3, Bacillus caldolyticus DSM405, Bacillus licheniformis GCBU-8 (Saxena et al., 2007; Asgher et al., 2007; Hamilton et al., 1999; Goyal et al., 2005; Schwab et al., 2009; Haq et al., 2003) since, Solid State Fermentation (SSF) replaces SmF as it mimics the natural habitat of microorganisms. SSF is alternative over SmF due to its low cost, lower energy requirement, simplicity, less water output, and lack of foam built up (Couto and Sanroman, 2006; Pandey, 2003; Tanyildizi et al., 2007). Biotechnological innovations particularly in the area of fermentation technology and enzyme technology, SSF with agro wastes such as WB, RB, COC, and GOC has replaced the high cost media generally used in submerged fermentation for alpha amylase preparation and Bacillus species are frequently used for $\alpha$-amylase production (Mulimani and Ramalingam, 1999; Shukla and Kar, 2006; Vijayabaskar et al., 2012; Baysal et al., 2003; Mukherjee
Sodhi et al., 2005; Soni et al., 2003). The present study mainly focused on screening of amylase producing Bacillus subtilis, production by solid-state fermentation using rice straw and banana pseudo stem and its optimization for amylase activity in dough preparation, effect on bread making and analysis of bread quality.

\section{MATERIAL AND METHODS}

\section{Isolation Of Bacillus subtilis from the environment}

A cut piece of cut potato was buried about four inches deep, and covered with soil. After about 6-8 days, the potato was digged out; the soil was scarped off and was taken it to the lab in the ziploc bag or a plastic bag. The amylase producer was isolated from that soil sample. $10 \mathrm{~g}$ of soil was suspended in $90 \mathrm{ml}$ of sterile distilled water, properly mixed. From the above, $10 \mathrm{ml}$ was transferred to $90 \mathrm{ml}$ of sterile distilled water. Two further dilutions were done in $90 \mathrm{ml}$ of sterile distilled water. $0.1 \mathrm{ml}$ of diluted sample was delivered in nutrient agar containing $1 \%$ (w/v) starch (corn starch) by means of pour plate techniques. The plate was incubated for $24 \mathrm{~h}$ at room temperature. Amylase producing colonies will have a clear area around them. To confirm, the plate was flood with Gram's iodine.

\section{Optimization of pH for amylase activity}

Nutrient agar containing $1 \%(\mathrm{w} / \mathrm{v})$ starch medium was prepared at different $\mathrm{pH}(3$ -10). The Bacillus sp. was streaked in the middle of the agar plates and incubated at room temperature for $24 \mathrm{~h}$. Amylase production was detected by the disappearance of blue colour around the colony when treated with iodine solution. Evaluation of the clear zones of each colony was estimated as radius $(\mathrm{mm})$ of the clear zone minus the radius of the colony.

\section{Bacterial amylase inoculation}

Bacillus subtilis was inoculated into the bacteriological amylase production media (Bacteriological peptone $-6 \mathrm{gm}, \mathrm{MgSO} 4.7 \mathrm{H} 2 \mathrm{O},-0.5 \mathrm{gm}$, KCl-0.5gm, Starch-1gm Water $-1000 \mathrm{ml}$ ) and incubated at room temperature for $24 \mathrm{~h}$. 
Amylase production by solid state fermentation

Two sets of fermentation were carried out in $250 \mathrm{ml}$ Erlenmeyer flasks containing production media (Rice bran/ Banana pseudo stem - $10 \mathrm{~g}$, Urea- $0.05 \%, \mathrm{MgCl} 2$ $0.25 \%$, KCl- $0.25 \%$,Sucrose- $1 \%$,Distilled water- $30 \mathrm{ml})$, which were autoclaved for $20 \mathrm{~min}$ at $121^{\circ} \mathrm{C}$. A cell suspension of $1 \%$ (v/w Rice bran/ Banana pseudo stem) containing viable cells/ml was used as inoculum. Incubation was carried out for $60 \mathrm{~h}$ at room temperature. Extraction was conducted using $10 \mathrm{~g}$ fermented mass in $250 \mathrm{ml}$ conical flask. Soaking the fermented solid with a suitable solvent like glycerol, acetone, isopropyl alcohol and water for desired period. The crude extract was then squeezed out through cheese cloth. The clear extract obtained after centrifugation to remove insoluble, assayed for amylolytic activity.

\section{Preparation of crude enzyme}

Dialysis will remove residual sugars from the enzyme mixture. One end of a dialysis tube was tied and enzyme mixture was poured into dialysis tube. The other end was tied securely. Dialysis tube was put in distilled water in a beaker. The water was changed several times for $24 \mathrm{~h}$. Crude enzyme was poured into clean Universal bottles or screw cap tubes and stored in a freezer at about $0^{\circ} \mathrm{C}$ until needed. The dialysis sample that was collected in a sterile bottom flask was rotated in ice at $45^{\circ}$ angles for the formation uniform thin layer of sample inside the flask and lyophilized. The enzyme powder collected from the flask was transferred into sterile vial and stored at $4^{\circ} \mathrm{C}$.

\section{Characterization of the crude enzyme}

The effect of temperature on the crude amylase activity was assayed at temperature values ranging from $20^{\circ} \mathrm{C}$ to $90^{\circ} \mathrm{C}$. The reaction mixture contained $0.1 \mathrm{ml}$ of the crude enzyme in $1 \mathrm{ml}$ of corn-starch $(1 \% \mathrm{w} / \mathrm{v})$. This was incubated for $30 \mathrm{mins}$ at each chosen temperature. At room temperature, to $5 \mathrm{ml}$ of crude enzyme $0.5 \mathrm{ml}$ of the extract was added and the enzyme activity was found by DNSA method and Bernfeld method (Bernfeld, 1955).

\section{Optimization of enzyme substrate concentration}

One unit of enzyme activity was defined as the amount of enzyme that release $1 \mu$ mole of reducing sugar as glucose per minute under the assay condition specified (Soumen and Rintu, 2001). 1 to $10 \mathrm{ml}$ of $1 \%$ starch solutions were taken in different test tube and made up to $1 \mathrm{ml}$ with distilled water. $1 \mathrm{ml}$ of crude enzyme was added to the above starch solution. Incubated in water bath $60^{\circ} \mathrm{C}$ for $3 \mathrm{~min}$ and the reaction was stopped by adding $1 \mathrm{ml}$ of DNSA reagent. The mixture was boiled for $5 \mathrm{~min}$ and brought to room temperature then $10 \mathrm{ml}$ of distilled water was added and absorbance was measured at 540nm.

\section{Optimization of enzyme concentration on dough preparation}

The flour used was commercial standard white wheat flour, containing $30 \mathrm{ppm}$ ascorbic acid, carbohydrate $73 \%$, Protein $9.5 \%$, fat $0.8 \%$, crude fibers traces, minerals $0.3 \%$ and moisture contents $11.7 \%$. Five different kinds of dough formulation were prepared for optimize the enzyme concentration. The above formulations prepared with $100 \mathrm{~g}$ of wheat flour, $25 \mathrm{ml}$ of water containing $150 \mathrm{U}$, $300 \mathrm{U}, 450 \mathrm{U}, 0.8 \mathrm{~g}$ yeast and $0.8 \mathrm{~g}$ yeast with $300 \mathrm{U}$ of amylase enzyme respectively. Then were kept for incubation at different period of time such as 0 , 15,30 minutes respectively. Six different dough formulations were given in the below table I.

\section{Table 1 Six different dough formulations}

\begin{tabular}{|l|c|c|c|c|c|c|}
\hline \multirow{2}{*}{$\begin{array}{l}\text { Ingredients } \\
\text { (in grams) }\end{array}$} & \multicolumn{7}{|c|}{ Types of Formulation } \\
\cline { 2 - 8 } & F1 & F2 & F3 & F4 & F5 & F6 \\
\hline Flour & 150 & 150 & 150 & 150 & 150 & 150 \\
\hline Dry yeast & - & 1.2 & - & - & 1.2 & 1.2 \\
\hline Gluten & 1 & 1 & 1 & 1 & 1 & 1 \\
\hline Amylase (Units) & - & - & 200 & 400 & 200 & - \\
\hline Salt & 3 & 3 & 3 & 3 & 3 & 3 \\
\hline Sugar & - & - & - & - & - & 3 \\
\hline Water (ml) & 75 & 75 & 75 & 75 & 75 & 75 \\
\hline Shortening & 3 & 3 & 3 & 3 & 3 & 3 \\
\hline
\end{tabular}

\section{Analysis of bread}

After baking the loaves volume were measured. Crumb stickiness, softness, and taste ware subjectively evaluated by well-experienced barking staff. A piece of crumb was squeezed between the thumb and two fingers for determine the stickiness of bread. Reducing sugar contents were analyzed by DNSA method. Softness was examined up to 7days. Reducing sugars were extracted from oneday bread crumb by mechanically stirring $2 \mathrm{~g}$ crumb with $20 \mathrm{ml}$ distilled water at $25^{\circ} \mathrm{C}$ for $25 \mathrm{~min}$ and centrifuged at $12000 \mathrm{rpm}$ for $15 \mathrm{~min}$. The extracts were stored frozen if not used immediately. The resulted dates were calculated and tabulated.

\section{RESULTS AND DISCUSSION}

\section{Screening of amylase producers}

Clear zone around the colony were seen (figure not shown) when the plates were treated with iodine. This indicated the colonies are amylase producers. Suman and Ramesh, (2010) reported that the screening of purified cultures was done on MAM (Minimal agar media) supplemented with 1\% starch the cultures growing in MAM were flooded with iodine solution and the zone of hydrolysis were obtained in the plates showing starch hydrolysis similar method in order to screen the microorganisms for amylase production.

\section{Optimization of pH}

$\mathrm{pH}$ and temperature have very important roles to play in amylase activity and stability. In this study the optimum $\mathrm{pH}$ range was found to be 7 but it works also in various $\mathrm{pH}$ ranges between 5 to 8 . The colonies, which were grown in different $\mathrm{pH}$ media was treated with iodine solution. The zone of clearance was absorbed maximum in the $\mathrm{pH} 7$ this indicate that the optimum $\mathrm{pH}$ for amylase production was 7 (Fig-1). Amylases are generally stable over a wide range of $\mathrm{pH}$ from 4 to 9 (Vihinen and Mantsala, 1989); however, according to Robyt et al. (1971) amylases with stability showed in a narrow range of $\mathrm{pH}$.

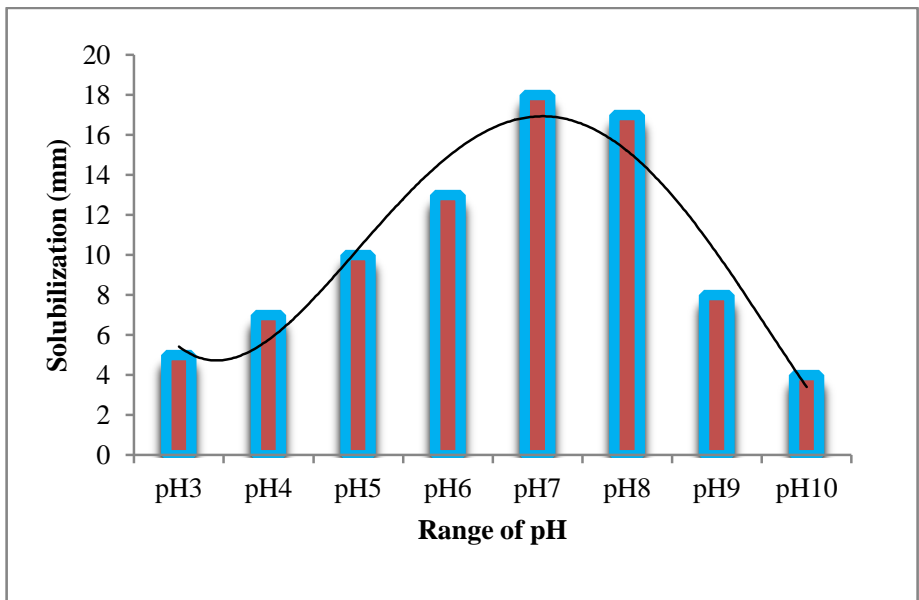

Figure 1 pH optimization by agar plate method

\section{Solvent extraction}

The extraction efficiency is critical to the recovery of the enzyme from the fermented biomass hence, selection of a suitable solvent is necessary. Different solvents selected were water, glycerol, and acetone. Among the solvent used glycerol gave the best result. Glycerol was found to be a suitable solvent to extract the extracellular amylase from the solid substrate fermentation medium. It showed the maximum release of $0.232 \mathrm{mg}$ and $0.216 \mathrm{mg}$ free glucose on banana pseudo stem and rice brawn substrate respectively followed by found to be isopropyl alcohol extraction (Table 2).

Table 2 Extraction of extra cellular enzyme from solid substrate by differed solvent systems

\begin{tabular}{|l|c|c|c|c|}
\hline Type of solvent & Glycerol & Acetone & $\begin{array}{c}\text { Isopropyl } \\
\text { alcohol }\end{array}$ & Water \\
\hline $\begin{array}{l}\text { Free glucose (mg)/ 5 } \\
\text { ml of Rice brawn as } \\
\text { substrate (1\%) }\end{array}$ & 0.216 & 0.091 & 0.201 & 0.121 \\
\hline $\begin{array}{l}\text { Free glucose (mg)/ 5 } \\
\text { ml of Banana } \\
\text { pseudo stem as } \\
\text { substrate (1\%) }\end{array}$ & 0.232 & 0.086 & 0.226 & 0.176 \\
\hline
\end{tabular}

Optimization of amylase enzyme activity

\section{Effect of pH on amylase activity}

The optimum $\mathrm{pH}$ was observed between the $\mathrm{pH}$ ranges of 5.0 - 8.0. After $\mathrm{pH} \mathrm{8}$, a continuous decrease in enzyme activity was observed (Fig-2). Previous report 
indicated the maximum production of amylase activity was obtained at $\mathrm{pH}$ of 7.0 (Mukesh et al.,2012).

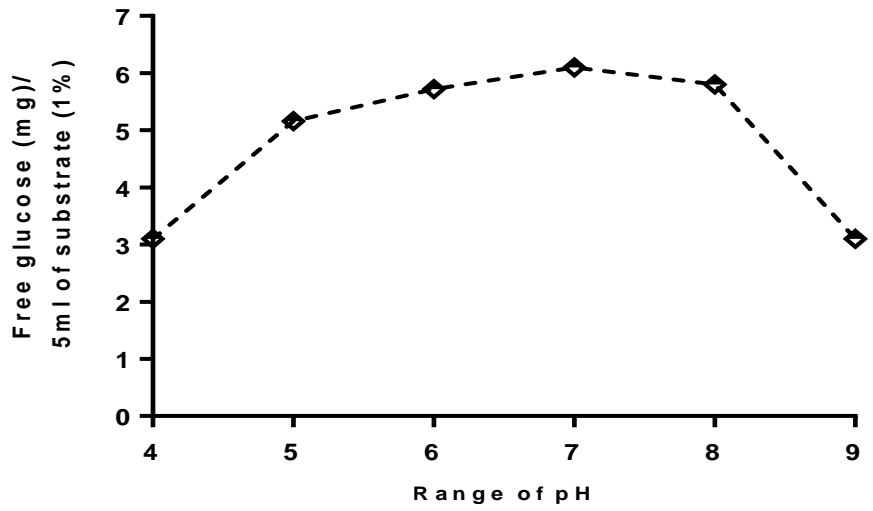

Figure 2 Effect of ph on amylase activity

\section{Effect of temperature on amylase activity}

The influence of temperature on amylase activity of the crude enzyme showed that enzyme activity increased progressively with increase in temperature from $20^{\circ} \mathrm{C}$ reaching a maximum at the range of $30-70^{\circ} \mathrm{C}$. Above $70^{\circ} \mathrm{C}$, there was a reduction in the amylase activity (Figure 3). Earlier studies indicated maximum amylase production occurred at the optimum growth temperature. The optimum temperature for enzyme activity was between $45^{\circ} \mathrm{C}$ and $55^{\circ} \mathrm{C}$ (Mukesh et al. 2012). A reduction in enzyme activity was observed at values above $60^{\circ} \mathrm{C}$. Mukesh kumar et al. (2012) reported the amylase activity attained its maximum at $50^{\circ} \mathrm{C}$ beyond which the enzyme activity was reduced gradually.

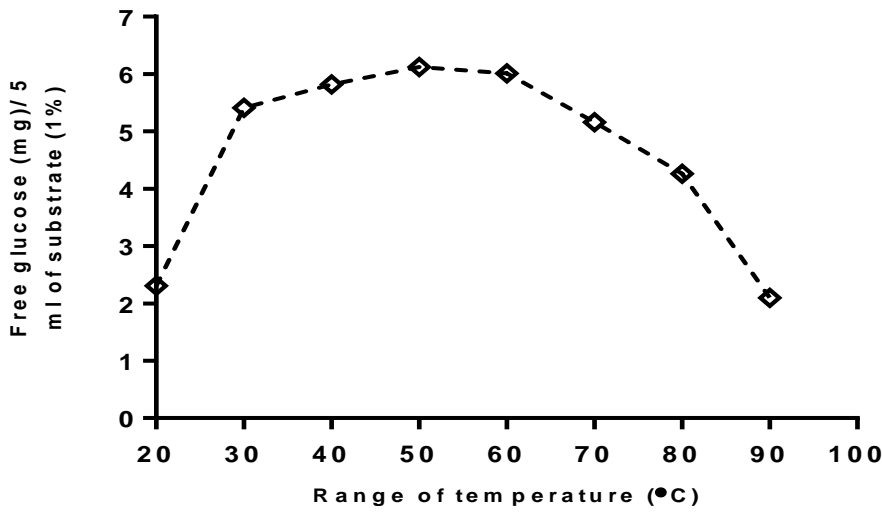

Figure 3 Effective on temperature on amylase activity

\section{Effect of starch concentration on amylase activity}

In the present study, amylase activity increased with increase in the starch concentration from $1 \mathrm{ml}$ to $10 \mathrm{ml}$ of $1 \%$ starch concentration (Fig-4). The production of enzyme is greatly dependent on the condition of growth of the culture and composition of nutrient medium. The medium constituents have been predicted to play an important role in enhancing the production of enzyme from microbial sources (Gupta et al., 2002).

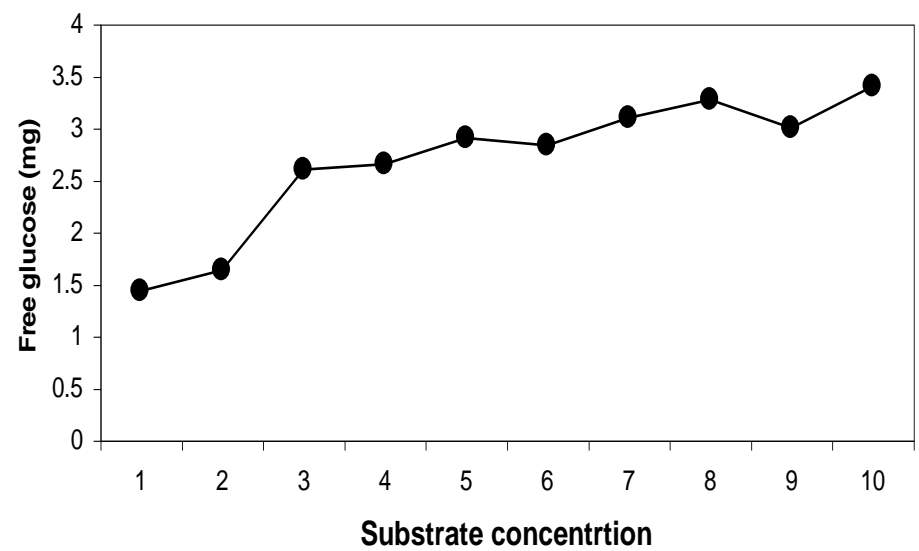

\section{Optimization of enzyme concentration on dough preparation}

The enzyme concentration was optimized based on the reducing sugar and incubation period. It was found to be $300 \mathrm{U}$ for $30 \mathrm{~min}$ at $27^{\circ} \mathrm{C}$ in $100 \mathrm{~g}$ of wheat flour. The combination of $0.8 \mathrm{~g}$ yeast and $300 \mathrm{U}$ of amylase gave better results than enzyme alone by means of dough volume. The detailed results were tabulated (Table- 3). Extra enzymes added to the dough improve control of the baking process, allowing the use of different baking processes, reducing process time, slowing-down staling, compensating for flour variability and substituting chemical additives (Tramper et al., 2005).

Table 3 Optimization of enzyme concentration on dough preparation

\begin{tabular}{|c|c|c|c|}
\hline Enzyme/yeast & $\begin{array}{c}\text { Flour } \\
\text { gm }\end{array}$ & $\begin{array}{c}\text { Incubation } \\
\text { period }\end{array}$ & $\begin{array}{l}\text { Reducing sugar } \\
\text { (mg/gm of dough) }\end{array}$ \\
\hline \multirow{3}{*}{ Amylase $150 \mathrm{U}$} & \multirow{3}{*}{100} & $0 \mathrm{~min}$ & 1.1 \\
\hline & & $15 \mathrm{~min}$ & 4.2 \\
\hline & & $30 \mathrm{~min}$ & 6.7 \\
\hline \multirow{3}{*}{ Amylase $300 \mathrm{U}$} & \multirow{3}{*}{100} & $0 \mathrm{~min}$ & 1.82 \\
\hline & & $15 \mathrm{~min}$ & 6.12 \\
\hline & & $30 \mathrm{~min}$ & 9.62 \\
\hline \multirow{3}{*}{ Amylase 450U } & \multirow{3}{*}{100} & $0 \mathrm{~min}$ & 2.27 \\
\hline & & $15 \mathrm{~min}$ & 9.16 \\
\hline & & $30 \mathrm{~min}$ & 13.72 \\
\hline \multirow{3}{*}{ Yeast $0.8 \mathrm{~g}$} & \multirow{3}{*}{100} & $0 \mathrm{~min}$ & 0.42 \\
\hline & & $15 \mathrm{~min}$ & 1.82 \\
\hline & & $30 \mathrm{~min}$ & 3.62 \\
\hline \multirow{3}{*}{$\begin{array}{l}\text { Yeast } \\
0.8 \mathrm{~g}+300 \mathrm{U} \\
\text { amylase }\end{array}$} & \multirow[b]{3}{*}{100} & $0 \min$ & 2.16 \\
\hline & & $15 \mathrm{~min}$ & 7.15 \\
\hline & & $30 \mathrm{~min}$ & 10.82 \\
\hline
\end{tabular}

Addition of $\alpha$-amylase gave moderate crumb firmness after 7 days of storage than without enzyme product. The moisture content in breadcrumb has been shown to decrease during storage (Herz, 1965). Addition of enzyme preparations caused significantly darker crusts (400U/150g of flour) compared to breads with $200 \mathrm{U}$ and addition of yeast products. This can be explained by increased formation of reducing sugars when $\alpha$-amylase is added and the estimated reducing sugar results were tabulated (Table-4) No differences were found between the other formulations like without enzyme, and without yeast products. The higher values for the intermediate resting time may be explained by assuming that, during the initial fermentation, the production of low-molecular weight sugars exceeded that metabolized by the yeast.

Table 4 estimation of reducing sugars of bread

\begin{tabular}{|l|c|}
\hline Types of formulation & $\begin{array}{c}\text { Reducing sugars } \\
\text { (mg/gm of bread) }\end{array}$ \\
\hline F1 & 3.1 \\
\hline F2 & 7.7 \\
\hline F3 & 14.23 \\
\hline F4 & 25.5 \\
\hline F5 & 20.6 \\
\hline F6 & 8.1 \\
\hline
\end{tabular}

\section{CONCLUSION}

Amylase producing Bacillus subtilis was isolated from soil (potato tuber). The amylase enzyme activity was optimized at various parameters like $\mathrm{pH}$, temperature and enzyme substrate concentration. It was found that the enzyme works wide ranges of $\mathrm{pH}(\mathrm{pH} 5-8)$ and the temperature ranges from $30^{\circ} \mathrm{C}$ to $60^{\circ} \mathrm{C}$. On SSF Banana pseudo stem reaches higher enzyme activity and glycerol was found to be a suitable solvent system for enzyme extraction. Crust darkness was significantly affected by addition of $\alpha$-amylses. Independent of added $\alpha$ amylase, resting time influences crust darkness, with maximum crust darkness obtained after $30 \mathrm{~min}$. Addition of $\alpha$ - amylase reduced the dependence of loaf volume on mixing time, but gave slightly significant increase in bread volume. The present study concluded that the combination of $\alpha$-amylase and yeast formulation showed better results compared with other formulations. So this enzyme system may be used under optimized concentration. Higher dosage of amylase gave high stickiness due to the formation of high levels of reducing sugars.

\section{REFERENCE}

ASGHER, M., ASAD, M.J., RAHMAN, S.U., LEGGE, R.L. 2007. A thermostable $\alpha$-amylase from a moderately thermophilic Bacillus subtilis strain for starch processing. Journal of Food Engineering, 79(3), 950-955. http://dx.doi.org/10.1016/j.jfoodeng.2005.12.053

Figure 4 Subtract concentration on amylase activity 
BAYSAL, Z., UYAR, F., AYTEKIN, C. 2003. Solid state fermentation for production of $\alpha$-amylase by a thermotolerant Bacillus subtilis from hot-spring water. Process Biochemistry, http://dx.doi.org/10.1016/S0032-9592(02)00150-4

$38(12), 1665-1668$

BERNFELD, P. 1955. Amylases, alpha and beta, In:Colowick, S. P. and Kaplan, N. O (eds.). Methods in enzymology. New York: Academic Press. 1. p. 149-158.

COUTO, S.R., SANROMAN, M.A. 2006. Application of solidstate fermentation to food industry-a review. Journal of Food Engineering, 76(3) 291-302. http://dx.doi.org/10.1016/j.jfoodeng.2005.05.022

FOGARTY, M.W. 1983. Microbial Amylases. In: W.M. Fogarty (eds.) Microbial Enzymes and Biotechnology, Applied Science Publishers Ltd, London, UK,p.1-92.

GOYAL, N., GUPTA, J.K., SONI, S. K. 2005. A novel raw starch digesting thermostable $\alpha$-amylase from Bacillus sp. I-3 and its use in the direct hydrolysis of raw potato starch. Enzyme and Microbial Technology, 37 (7), 723-734 http://dx.doi.org/10.1016/j.enzmictec.2005.04.017

GUPTA, R., BEG, Q.K., KHAN, S., CHAUHAN, B. 2002. An overview on fermentation, downstream processing and properties of microbial alkaline proteases. Appl. Microbiol. Biotechnol., 60, 381-395. http://dx.doi.org/10.1007/s00253-002-1142-1

GUPTA, R., GIGRAS, P., MOHAPATRA, H., GOSWAMI, V.K., CHAUHAN, B. 2003. Microbial $\alpha$-amylases: a biotechnological perspective. Process Biochem 38, 1599 - 1616. http://dx.doi.org/10.1016/S0032-9592(03)00053-0

HAMILTON, L.M., KELLY, C.T., FOGARTY, W.M. 1999. Production and properties of the raw starch-digesting $\alpha$-amylase of Bacillus sp. IMD 435 Process Biochemistry, 35(1-2), 27-31. http://dx.doi.org/10.1016/S00329592(99)00028-X

HAQ, I.U., ASHRAF, H., IQBAL, J., QADEER, M.A. 2003. Production of alpha amylase by Bacillus licheniformis using an economical medium. Bioresource Technology, 87 (1), 57-61. http://dx.doi.org/10.1016/S0960-8524(02)00198-0

Herz, K. 0. 1965. Staling of bread - a review. Food Technology, 19, 90-103

KANDRA, L. 2003. $\alpha$-Amylases of medical and industrial importance. Journal of Molecular Structure (Theochem), Volume 666-667.pp.487-498. http://dx.doi.org/10.1016/j.theochem.2003.08.073

MUKESH KUMAR, D.J., ANDAL PRIYADHARSHINI, D., SURESH, K. SARANYA, G.M., RAJENDRAN, K., KALAICHELVAN, P.T. 2012. Production, Purification and Characterization of $\alpha$-Amylase and Alkaline Protease by Bacillus sp. HPE 10 in a Concomitant Production Medium. Asian Journal of Plant Science and Research, 2 (3), 376-382.

MUKHERJEE, A.K., BORAH, M., RAI, S.K. 2009. To study the influence of different components of fermentable substrates on induction of extracellular $\alpha$ amylase synthesis by Bacillus subtilis DM-03 in solid-state fermentation and exploration of feasibility for inclusion of $\alpha$-amylase in laundry detergen formulations. Biochemical Engineering Journal, 43(2), 149-156. http://dx.doi.org/10.1016/j.bej.2008.09.011

MULIMANI, V.M., RAMALINGAM, G. N. P. 1999. $\alpha$-Amylase production by solid state fermentation: a new practical approach to biotechnology courses Biochemical Education, 28(3), 161-163. http://dx.doi.org/10.1111/j.1539. 3429.2000.tb00056.x

NIGAM, P., SINGH, D. 1995. Enzyme and microbial systems involved in starch processing. Enzyme and Microbial Technology, 17(9), 770-778. http://dx.doi.org/10.1016/0141-0229(94)00003-A

PANDEY, A. 2003. Solid-state fermentation. Biochemical Engineering Journal, 13 (2-3), 81-84, http://dx.doi.org/10.1016/S1369-703X(02)00121-3

PANDEY, A., SOCCOL, C.R., MITCHELL, D. 2000. New developments in solid state fermentation. Process Biochem, 35, 1153-1169. http://dx.doi.org/10.1016/S0032-9592(00)00152-7

RAJAGOPALAN, G., KRISHNAN, C. 2008. Alpha-amylase production from catabolite derepressed Bacillus subtilis KCC103 utilizing sugarcane bagasse $\begin{array}{llll}\text { hydrolysate. } & \text { Bioresour } & \text { Technol } & \text { 99, }\end{array}$ http://dx.doi.org/10.1016/j.biortech.2007.06.001
RAMESHKUMAR, A., SIVASUDHA, T. 2011. Optimization of nutritional constitute for enhanced $\quad \alpha$-amylase production by solid state fermentation technology. International Journal of Microbiological Research, 2(2), 143-148.

RAO, M.B., TANKSALE, A.M., GATHE, M.S., DESHPANDE, V.V. 1998 Molecular and Biotechnological aspects of microbial proteases. Microbial. Microbial. Rev, 62, 597-635.

ROBYT, J., ACKERMAN, R. J. 1971. Isolation, purification and characterization of a maltotetraose producing amylase from Pseudomonas stutzeri. Arch. Biochem. Biophys, 145, 105-114. http://dx.doi.org/10.1016/0003-9861(71)90015-4

SAXENA, R.K., DUTT, K., AGARWAL, L., NAYYAR, P. 2007. A highly thermostable and alkaline amylase from a Bacillus sp. PN5. Bioresource Technology, 98(2), 260-265. http://dx.doi.org/10.1016/j.biortech.2006.01.016

SCHWAB, K., BADER, J., BROKAMP, C., POPOVIC, M. K., BAJPAI, R., BEROVIC, M. 2009. Dual feeding strategy for the production of $\alpha$-amylase by Bacillus caldolyticus using complex media. New Biotechnology, 26(1-2), 68-74 http://dx.doi.org/10.1016/j.nbt.2009.04.005

SHUKLA, J., KAR, R. 2006. Potato peel as a solid state substrate for thermostable $\alpha$-amylase production by thermophilic Bacillus isolates. World Journal of Microbiology and Biotechnology, 22(5), 417-422. http://dx.doi.org/10.1007/s11274-005-9049-5

SIDHU, G.S., SHARMA, P., CHAKRABARTI, T., GUPTA, J.K. 1997. Strain improvement for the production of a thermostable alpha amylase by Bacillus species. Enz. Microbial Technol, 21, 525-530. http://dx.doi.org/10.1016/S01410229(97)00055-0

SODHI, H.K., SHARMA, K., GUPTA, J.K., SONI, S.K. 2005. Production of a thermostable $\alpha$-amylase from Bacillus sp. PS-7 by solid state fermentation and its synergistic use in the hydrolysis of malt starch for alcohol production. Process Biochemistry, 40(2), 525-534. http://dx.doi.org/10.1016/j.procbio.2003.10.008

SONI, S.K., KAUR, A., GUPTA, J.K. 2003. A solid state fermentation based bacterial $\alpha$-amylase and fungal glucoamylase system and its suitability for the hydrolysis of wheat starch. Process Biochemistry, 39(2), 185-192. http://dx.doi.org/10.1016/S0032-9592(03)00058-X

SOUMEN, P., RINTU, B. 2001. Optimization of extraction parameters for the recovery of a-amylase from the fermented bran of Bacillus circulans GRS313. Braz. arch. boil. Technol, 44(1), 1-9.http://dx.doi.org/10.1590/S1516$\underline{89132001000100015}$

SUMAN, S., RAMESH, K. 2010, Production of a thermostable extracellula amylase from thermophilic Bacillus species. Pharm. Sci. \& Res. 2: 149-154.

TANYILDIZI, M.S., OZER, D., ELIBOL, M. 2007. Production of bacterial $\alpha$ amylase by $B$. amyloliquefaciens under solid substrate fermentation. Biochemical

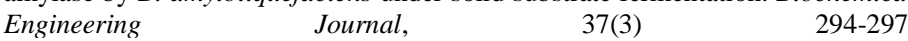
http://dx.doi.org/10.1016/j.bej.2007.05.009

TRAMPER, J., POULSEN, P.B. 2005. Enzymes as Processing Aids and Final Products. In: Straathof AJJ, Adlercreutz P. (eds.) Applied Biocatalysis, second ed. Amsterdam: Harwood Academic Publications, p. 62-102.

VIHINEN, M., MANTSALA, P. 1989. Microbial amylolytic enzymes. Crit. Rev. Biochem. Mol. Biol. 24, 329-418. http://dx.doi.org/10.3109/10409238909082556

VIJAYABASKAR, P., JAYALAKSHMI, D., SHANKAR, T. 2012. Amylase production by moderately halophilic Bacillus cereus in solidstate fermentation African Journal of Microbiology Research, 6, 4918-4926. 